\title{
The Effect of Steaming on The Color and Amount of Anthocyanin of Purple Sweet Potato Flour
}

\author{
Ai Mahmudatussa'adah ${ }^{1}$, Rita Patriasih ${ }^{2}$, Rijanti Rahayu Maulani ${ }^{3}$, Karpin $^{4}$ \\ \{aims@upi.edu ${ }^{1}$, ritapatriasih@upi.edu², rijanti@sith.itb.ac.id ${ }^{3}$, Karpin@upi.edu $\left.{ }^{4}\right\}$ \\ Universitas Pendidikan Indonesia ${ }^{1,2,4}$, Institut Teknologi Bandung ${ }^{3}$
}

\begin{abstract}
Purple sweet potato is one of the potential sources of antioxidants. Anthocyanin in purple sweet potato is naturally to get enzymatic oxidation after contact with oxygen. The oxidation process causes the brown color to show a decrease in the amount of anthocyanin. The oxidation process was caused due to enzymatic activity. The aims of this study was to determine the influence of steaming on the color and total of anthocyanin monomeric sweet potato flour. This research was used trial method. In this research, the stages carried were material preparation, steaming, drying, grinding, and sieving. Color analysis using chromameter, and total anthocyanin amount using the $\mathrm{pH}$ difference method. The results showed that the steaming process gave bluish-purple, and the amount of anthocyanin was higher than without steaming. This study implies that the steaming process of sweet potatoes can maintain the purple color and total monomeric anthocyanin of fresh sweet potatoes.
\end{abstract}

Keywords : Anthocyanin, Flour, Purple sweet potato, Steaming

\section{Introduction}

Purple sweet potatoes generally have a relatively short shelf life. Purple sweet potato contains carbohydrates, protein, fat, fiber, and anthocyanin. Anthocyanin purple sweet potato is relatively resistant to heating because it contains anthocyanin acylated [1]. Purple sweet potato contain of peonidin 3-caffeoyl-sophoroside-5-glucoside and cyanidin 3-caffeoyl-sophoroside-5-glucoside [2]. Base on $[1,4,5]$ reported that acylated anthocyanin is stable again the change of heat and $\mathrm{pH}$. Anthocyanins can function as antioxidants and antimutagenic. Because of its nutritional and phytochemical content, purple sweet potato is very potential to be used as a functional food source. To extend shelf life and make easier utilization of purple sweet potatoes can be made into flour.

Flour is a dry solid preparation with fine granules of $80-100$ mesh size depending on the grinding process. Flour is widely used for various household or industrial purposes. Flour also has a relatively long shelf life for storing it the right way. The stages of the process of making sweet potato flour include the sorting and cleaning of tubers, stripping, washing, slicing, drying, flouring, and sifting. Purple sweet potato contains phenol and polyphenol oxidase peroxidase enzymes, which, when in contact with air (oxygen), can cause browning reactions [6]. The process of making purple sweet potato flour, is a stripping process, so that phenol and phenolase enzymes in contact with oxygen cause an oxidation process. The alternative way to inactivate the phenolase enzyme is by steaming. The phenolase enzyme is a protein that can be denatured by acid or heat treatment. Acid treatment can cause a typical acid flavor. The purpose of this study to stop the anzyme activity was by steaming in a short time. 


\section{Materials and Methode}

The material used in this study was the purple sweet potato var Ayamurasaki with a planting period of 5 months. Purple sweet potatoes are washed, drained and stored in a dry and covered place. Chemicals used include sodium acetate, potassium chloride, hydrochloric acid, methanol obtained from Merck Germany. The tools used for the analysis chromameter equipment Minolta CR 310, and UV-Vis spectrophotometer.

\subsection{Purple Sweet Potatoes Flour Preparation}

Purple sweet potato flour was made by way of sweet potatoes that have been washed and dried then peeled using a stainless steel peeler, sliced, steamed for 4 minutes, dried in an oven at $60{ }^{\circ} \mathrm{C}$ for 12 hours, grounded, and sieved with 80 mesh sieve. PSP flour is packed in a plastic bag. Samples were stored in the freezer until ready to be analyzed.

\subsection{Anthocyanin Extraction}

Anthocyanin extraction was carried out by means of purple sweet potato flour weighed as much as 1 gram, then dissolved in $15 \%$ solution of methanol and hydrochloric acid $(1.5 \mathrm{M}$ in methanol), put into Erlenmeyer glass, stored in shaking water baths at $50{ }^{\circ} \mathrm{C}$ for one hour. Purple sweet potato flour suspense and hydrochloric acid methanol solution then centrifuged at 4000 rpm for fifteen minutes. The supernatant was decanted, and the solid is extracted again in the same way as previously. Supernatants obtained from extraction 1 and 2 were put together and evaporated using a rotary evaporator at $40{ }^{\circ} \mathrm{C}$, turning $4 \mathrm{rpm}$ for 20 minutes. Concentrated anthocyanin extracts are stored in dark bottles, and stored in refrigerators until they were ready for analysis.

\subsection{Color Measurement}

The color measurement base on CIELAB method Before measuring the sample, the instrument was calibrated by using a white calibration sample, with $\mathrm{L} *=92.75$, a $*=-0.76$, and $b^{*}-0.07$. To measure $\mathrm{C}$ and $\mathrm{H}$ is based on data $\mathrm{L} * \mathrm{a} *$, and $\mathrm{b} *$. Sweet potato flour (sample) is put into a petri dish, flattened, covered, then measured using a colorimeter. This color measurement uses the CIELAB system, with the parameter L* showing brightness, a * $(+)$ indicates the range of red, $\mathrm{a} *(-)$ indicates green $(-), \mathrm{b} *(+)$ indicates yellow, $\mathrm{b} *(-)$ shows blue. The parameter $C$ shows the color intensity calculated using the formula: $C=\sqrt{a^{* 2}+b^{* 2}}$. Hue (H) represents the color angle, from $0^{\circ}$ to $360^{\circ}$. When $\mathrm{H}$, the angle of $0^{\circ}$ indicates red, which is $\mathrm{a}^{*}(+)$, while Hue $90^{\circ}$ indicates yellow or $\mathrm{b} *(+)$ quadrant. Hue $180^{\circ}$ shows green $\mathrm{a}^{*}(-)$, and Hue $360^{\circ}$ shows blue $b *(-)$. Hue $=\tan ^{-1}(a * / b *)$.

\subsection{Monomeric Anthocyanin Analysis}

To measure the monomeric anthocyanin in this research based on differences in $\mathrm{pH}$. Anthocyanins can change color at $\mathrm{pH}$ one and $\mathrm{pH} 4.5$ due to changes in their chemical structure $[1,9]$. A total of $1 \mathrm{~mL}$ of concentrated anthocyanin extract, put into a $5 \mathrm{~mL}$ volume flask, then beaten with a $0.025 \mathrm{M}$ potassium chloride buffer solution, $\mathrm{pH}$ one until the marker. To another $5 \mathrm{~mL}$ volume flask, one $\mathrm{mL}$ of concentrated anthocyanin extract was added, then a $0.4 \mathrm{M}$ sodium acetate buffer solution with $\mathrm{pH} 4.5$ was added until exactly $5 \mathrm{ml}$ in volume. The two samples 
are then stored in a dark place for one hour, so they form a stable equilibrium. Then the absorbance samples are measured using a UV-Vis spectrophotometer at wavelengths that provide maximum absorption. The spectrophotometer is calibrated by measuring blanks at a wavelength of $700 \mathrm{~nm}$. Monomeric anthocyanins are expressed as equivalent to cyanidin 3glucoside in $\mathrm{mg} . \mathrm{L}^{-1}$. The following equation calculates monomeric anthocyanin:

Monomeric Anthocyanin : $\frac{A x B M X F P X 1000}{\in x l}$

Information :

A is absorbance.

$A_{\lambda v i s-\max }$ is the absorption at the maximum wavelength in the area of visible light

$\mathrm{Mr}$ is the relative molecular mass of cyanidin-3-glucoside (449.2 $\mathrm{g} \mathrm{mol}^{-1}$ )

$\mathrm{DF}$ is the dilution factor

1000 is a conversion mass from grams to milligrams

$\varepsilon$ is the molar absorptivity of Cyanidine $26900 \mathrm{~L}^{\mathrm{c}} \mathrm{cm}^{-1} \mathrm{~mol}^{-1}$

1 is the length of the cuvvet $(1 \mathrm{~cm})$

The maximum absorbance, the sample is measured at wavelengths of $350 \mathrm{~nm}$ to 700 $\mathrm{nm}$. The maximum absorbance for $\mathrm{pH}$ one samples is at the wavelength of visible light $521 \mathrm{~nm}$ and at $\mathrm{pH} 4.5$ at the wavelength of visible light $544 \mathrm{~nm}$, indicating it is still in the red wavelength range. All measurements were carried out three times.

\section{Results and Discussion}

\subsection{Discoloration}

Fresh PSP contains $67 \%$ of water. After the steaming process, the moisture content increased to $74 \%$, and after the siege became $16 \%$. The steaming process can denature proteins, so that the enzyme anthocyanase, the peroxidase enzyme, and the polyphenol oxidase enzyme become inactive in oxidizing the anthocyanin $[12,13]$. The steaming process can generally strengthen the color, due to the breaking of bonds between the protein and the dye, so that the color becomes more out.
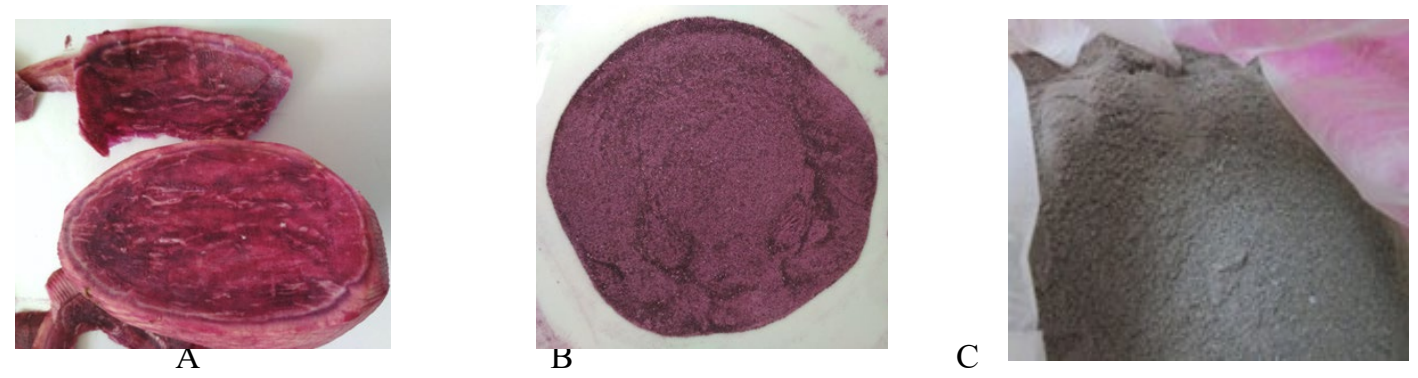

Figure 1. Purple Sweet Potato A: Fresh (PSF), B: Flour with Steam Process (PSS), and C: Flour Without Steam process (PSN) 
Figure 1A showing the colour of fresh sweet potatoes, not yet undergoing further treatment. Figure 1B shows purple sweet potato flour, which was steamed before being dried and poured. Figure 1C shows purple sweet potato flour, which did not experience steaming before drying and flouring. Based on color measurements, using chromameters obtained data as listed in Table 1. The characteristics of fresh purple sweet potato (PSF) colour (Figure 1A), different from purple sweet potato flour with the steaming process (PSS) (Figure 1B), and purple sweet potato flour without steaming (PSN) (Figure 1C). The characteristic color of the sample was confirmed by measurement with a colorimeter Minolta and differed significantly (Table 1). This color measurement follows the CIELAB coordinates with parameters $\mathrm{L}^{*}, \mathrm{a}^{*}$ and $\mathrm{b}^{*}$, and coordinates $\mathrm{C}$ (Chromaticity) and $\mathrm{H}$ (Hue). In addition to the heating process, the appearance of anthocyanin colors is strongly influenced by $\mathrm{pH}$. At $\mathrm{pH} \mathrm{1-3,} \mathrm{the} \mathrm{color} \mathrm{is} \mathrm{red,} \mathrm{pH} 4$ to $\mathrm{pH} 6$ is pink, at $\mathrm{pH}$ seven is blue, at $\mathrm{pH} 8, \mathrm{pH} 9$ is green, and at $\mathrm{pH} 10$ to $\mathrm{pH} 14$ is yellow. Differences in color indicate changes in the structure of anthocyanins $[14,15,16]$.

Table 1. Colour characteristics of PSF, PSS, and PSN

\begin{tabular}{crrrrr}
\hline Sample PSP & $\mathrm{L}^{*}$ & $\mathrm{a}^{*}$ & $\mathrm{~b}^{*}$ & $\mathrm{C}$ & Hue $\left({ }^{\circ}\right)$ \\
\hline PSF & $35.26 \pm 0.11^{\mathrm{b}}$ & $12.28 \pm 0.03^{\mathrm{b}}$ & $-2.93 \pm 0.06^{\mathrm{c}}$ & $12.63 \pm 0.04^{\mathrm{b}}$ & $346.67 \pm 0.25^{\mathrm{a}}$ \\
PSS & $42.20 \pm 0.07^{\mathrm{a}}$ & $16.03 \pm 0.09^{\mathrm{a}}$ & $-7.02 \pm 0.03^{\mathrm{a}}$ & $17.50 \pm 0.09^{\mathrm{a}}$ & $336.43 \pm 0.06^{\mathrm{b}}$ \\
PSN & $24.17 \pm 0.04^{\mathrm{c}}$ & $6.21 \pm 0.03^{\mathrm{c}}$ & $-4.84 \pm 0.02^{\mathrm{b}}$ & $7.86 \pm 0.02^{\mathrm{c}}$ & $322.13 \pm 0.23^{\mathrm{c}}$ \\
\hline
\end{tabular}

PSF: Fresh Purple Sweet Potato, PSS: PSP Flour with Steam process, PSN: PSP Flour did not steam process; $\mathrm{L} *$ (Lightness, brightness), a * (redness) $b *$. (Yellowness), $\mathrm{C}$ (chromaticity). The numbers that followed by different letters in the same column show the test results are significantly different $(\mathrm{P}<0.05)$

Previous researchers [10] suggested that the color characteristics of Chickenurasaki purple sweet potato flour are $\mathrm{L}^{*}: 44.0, \mathrm{a} *: 21.6, \mathrm{~b} *$ : -6.7 and hue: -0.3 , radians: $342.88^{\circ}$, and according to [11] the color characteristics of Ayamurasaki PSP flour are L: 42.08, a *: 13.04, $\mathrm{b} *$ : -2.88 , and hue: 347.7 , almost the same as the PSS color characteristics in this study. The dominant cyanidin in purple sweet potato is the dominant, which gives a blue color, and the peonidin dominant gives a red color [12].

\subsection{Monomeric Anthocyanin Concentration}

The amount of anthocyanin monomeric in this study was measured by the $\mathrm{pH}$ differences method and equalized by the amount of cyanidin-3-glucoside. The amount of anthocyanin in the sample is shown in Table 2. The highest amount of anthocyanin is owned by a sample of purple sweet potato flour, which undergoes a steaming process (PSS), followed by fresh purple sweet potato (PSF), and the lowest amount of anthocyanin is purple sweet potato flour without steaming (PSN). The amount of anthocyanin PSF is lower than PSS because, during preparation for drying and analysis, the sample has undergone oxidation. Purple sweet potatoes are very easily oxidized by contact with oxygen, causing enzymatic browning reactions. Purple sweet potato flour without the steaming process has the lowest amount of anthocyanin due to various treatments that decrease the amount of anthocyanin. In the process of making flour, there are stripping, slicing, drying, and grinder processes. Starting from the process of stripping, slicing and 
drying contact occurs between anthocyanin, anthocyanase enzymes, and air so that the browning process occurs. In contrast to the steaming treatment, when slicing is directly hit by hot steam, the enzyme anthocyanase or phenolase enzyme is denatured so that it becomes inactive. If the enzyme is inactive, the oxidation process will not continue. The process of oxidation and heating causes the amount of anthocyanin to decrease.

Table 2. Fresh monomeric anthocyanin content of PSF, PSS, and PSN

\begin{tabular}{lc}
\hline \multicolumn{1}{c}{ Sample } & Concentration of anthocyanin mg CyE/g (db) \\
\hline Fresh Purple Sweet Potato (PSF) & $2.42 \pm 0.12^{\mathrm{b}}$ \\
Flour With Steam PSP (PSS) & $2.99 \pm 0.07^{\mathrm{a}}$ \\
Flour Not Steam PSP (PSN) & $1.52 \pm 0.03^{\mathrm{c}}$ \\
\hline
\end{tabular}

The numbers followed by different letters in the same column show the test resultsvare significantly different $(\mathrm{P}<0.05)$, db: dry base

The results of this study are the same as the study [13], which concluded the steaming process for 25 minutes could increase the monomeric concentration of anthocyanin in some sweet potato varieties. However, it does not significantly increase the total amount of anthocyanin. Other researchers report that the monomeric concentration of anthocyanin increased by 4.5 -fold after the steaming process, which was 4.2 -fold after boiling, and 3.34 times after roasting [17]. Different results were reported [17,18]. The concentration of anthocyanin in Shinzami varieties decreased by half after the vacuum steaming process at $121^{\circ} \mathrm{C}$ for 10 minutes and slightly reduced after the burning process at $200{ }^{\circ} \mathrm{C}$ for $40-50$ minutes.

The lowest monomeric anthocyanin concentration was PSN, which shows the activity of anthocyanase enzymes, polyphenols oxidase and peroxidase, which reduce anthocyanin content and change anthocyanin color through oxidation reactions. According to [12], the color change in purple sweet potato at room temperature is related to a decrease in polyphenols by the activity of anthocyanase enzymes, polyphenols oxidase, and peroxidase. Based on [19] reported the polyphenol oxidase enzyme found in purple fleshy potatoes was very active at room temperature and degraded at temperatures higher than 70 ${ }^{\circ} \mathrm{C}$. The steaming or freezing process of slice fresh sweet potato before the extraction of anthocyanin and phenolics damage [13].

Monomeric anthocyanin concentrations from PSS are higher than fresh PSF and PSN. The PSF and PSN samples both of them were an oxidation process. PSN has the smallest amount of anthocyanin, due to oxidation and heating to dry. Some previous researchers found the highest anthocyanin in the Chickenurasaki sweet potato flour was $1.88 \mathrm{mg}$ Cy-3-glucoside / g flour [11]. According to [20] PSP anthocyanin concentration $1.38 \mathrm{mg} / \mathrm{g}$. The amount of monomeric anthocyanin from this study is different from the results of previous studies. This difference is due to differences in raw materials and flour making techniques. In this study, fresh PSP concentrations were higher in number than [20] Various factors can cause this. The polyphenol oxidase enzyme in purple flesh potatoes is very active at room temperature and is damaged at temperatures above $70{ }^{\circ} \mathrm{C}$ [19]. Researchers [13] reported that the steaming or freezing process of fresh sweet potato slices before anthocyanin extraction could minimize the damage of phenolic compounds and anthocyanins 


\section{Conclusion}

The steaming process before the drying process of purple sweet potato slices can strengthen the natural color of the purple sweet potato, and the amount of anthocyanin is relatively increased. The steaming process can denature the oxidizing enzyme protein so that the enzyme becomes inactive. The amount of anthocyanin is correlated with the fresh color of purple sweet potato.

\section{Acknowledgments.}

This study was funded by the Ministry of Research, Technology, and Higher Education Republik of Indonesia through Penelitian Terapan Unggulan Perguruan Tinggi scheme 2019, facilitated by Universitas Pendidikan Indonesia.

\section{References}

[1] Jie, L., Xiao-ding, L., Yun, Z., Zheng-dong, Z., Zhi-ya, O., Meng, L., Shao-hua, Z., Shuo, L., Meng, W., dan Lu, O.: Identification and thermal stability of purple-fleshed sweet potato anthocyanins in aqueous solutions with various $\mathrm{pH}$ values and fruit juices. Food Chemistry Vol 136, pp. 1429-1434 (2013)

[2] Montilla, E.C., Hillebrand, S., dan Winterhalter P.: Anthocyanins in Purple Sweet Potato (Ipomoea batatas L.) Varieties. Fruit, Vegetable and Cereal Science and Biotechnology 5 (Special Issue 2). pp. 19-24 (2011)

[3] Tsukui, A., Murakami, T., Shiina, R., dan Hayashi, K.: Effect of alcoholic fermentation on the stability of purple sweet potato anthocyanins. Food Science and Technology Research Vol.8 pp. 4-7 (2002)

[4] Cevallos-Casals, B.A. dan Cisneros-Zevallos, L.: Stability of anthocyanin based aqueous extracts of Andean purple corn and red-fleshed sweet potato compared to synthetic and natural colorants. Food Chemistry Vol. 86. pp. 69-77 (2004)

[5] Kano, M., Takayanagi, T., Harada, K., Makino, K., dan Ishikawa, F.: Antioxidative activity of anthocyanins from purple sweet potato, Ipomoea batatas cultivar Ayamurasaki. Bioscience, Biotechnology and Biochemistry Vol 69. pp. 979-988 (2005)

[6] Krishnan, J.G., Padmaja, G., Moorthy, S.N., Suja, G., dan Sajeev, M.S.: Effect of presoaking treatments on the nutritional profile and browning index of sweet potato and yam flours. Innovative Food Science and Emerging Technologies Vol. 11. pp. 387$393(2010)$

[7] Huang, C.L., Liao, W.C., Chan, C.F., dan Lai, Y.C.: Optimization for extraction anthocyanin from purple sweet potato roots using response surface methodology. Journal of Taiwan Agricultural Research Vol. 59, pp. 143-150 (2010)

[8] Truong, V.D., Hua, Z., Thompson, R.L., Yencho, G.C., dan Pecota, K.V.: Pressurized liquid extraction and quantification of anthocyanins in purple-fleshed sweet potato genotypes. Journal of Food Composition and Analysis. Vol. 26, pp. 96-103 (2012)

[9] Lee, J., Durst, W., dan Wrolstad, R.E.: Determination of total monomeric anthocyanin pigment content of fruit juices, beverages, natural colorants, and wines by the $\mathrm{pH}$ differential method: Collaborative study. Journal of AOAC International 88: 1269 1278 (2005) 
[10] Oki, T., Masuda, M., Furuta, S., Nishiba, Y. Terahara, N. dan Suda, I.: Involvement of anthocyanins and other phenolic compounds in radical-scavenging activity of purplefleshed sweetpotato cultivars. Journal of Food Science. Vol. 67: 1752-1756 (2002)

[11] Husnah, S.: Pembuatan tepung ubi jalar ungu (Ipomoea batatas varietas Ayamurasaki) dan aplikasinya dalam pembuatan roti tawar. [Skripsi]. Bogor: Fakultas Teknologi Pertanian, Institut Pertanian Bogor. (2010)

[12] Shi, Z., Bassa, I. A., Gabriel, S. L., dan Francis, F. J.: Anthocyanin pigments of sweetpotatoes Ipomoea batatas. Journal of Food Science. Vol. 57. pp. 755-770 (1992)

[13] Truong, V.D., Deighton, N., Thompson, R.T., Mc Feeters, R.F., Dean, L.O., Pecota, K.V., dan Yencho, G.C.: Characterization of anthocyanins and anthocyanidins in purple-fleshed sweetpotatoes by HPLC-DAD/ESI-MS/MS. Journal of Agriculture and Food Chemistry. Vol. 58. pp. 404-410 (2010)

[14] Mahmudatussa'adah,A., Fardiaz,D., Andarwulan,N., Kusnandar, F.: Color characteristics and antioxidant activity of anthocyanin extract from purple sweet potato. Jurnal Teknologi dan Industri Pangan, Vol. 25. pp. 176-184 (2014)

[15] Março P.H., Poppi, R.J., Scarminio, I.S., Tauler, R.: Investigation of the pH effect and UV radiation on kinetic degradation of anthocyanin mixtures extracted from Hibiscus acetosella. Food Chemistry Vol. 125. pp. 1020-1027 (2011)

[16] Suda I, Oki T, Masuda M, Kobayashi M, Nishiba Y, Furuta S. Physiological functionality of purple-fleshed sweet potatoes containing anthocyanins and their utilization in foods-Review. Japan International Research Center Agriculture Science. Vol. 37. pp.167-173 (2003)

[17] Lachman, J., Hamouz, K., Orsak, M, Pivec, V., Hejtmankova, K., Pazderu, K., dan Dvor`ak, P., C`epl J.: Impact of selected factors - Cultivar, storage, cooking and baking on the content of anthocyanins in coloured-flesh potatoes. Food Chemistry Vol. 133. pp. 1107-1116 (2012)

[18] Kim, H.W., Kim, J.B., Cho, S.M., Chung, M.N., Leen, Y.M., Chu, S.M., Che, J.H., Kim, S.N., Kim, S.Y., Cho, Y.S., Kim, J.H., Park, H.J. dan Lee, D.J.: Anthocyanin Shinzami, as affected by steaming and baking. Food Chemistry, Vol 130, pp. 966-972 (2012)

[19] Jang, J., Ma, Y., Shin, J., dan Song, K.: Characterization of polyphenoloxidase extracted from Solanum tuberosum Jasim. Food Science Biotechnologhi. Vol. 14: 117-122 (2005)

[20] Jiao, Y., Jiang, Y., Zhai, W. dan Yang, Z.: Studies on antioxidant capacity of anthocyanin extract from purple sweet potato (Ipomoea batatas L.) African Journal of Biotechnology, Vol. 11, pp. 7046-7054 (2012) 